\title{
INFLUENCE OF POTASSIUM DEFICIENCY IN A MEDIUM ON THE PHYSIOLOGICAL REACTION OF SEEDLINGS OF NEW RYE LINES
}

\author{
Anna Stolarska, Jacek Wróbel, Krystyna Przybulewska, \\ Joanna Błaszczyk, Michalina Okurowska \\ Chair of Plant Physiology \\ Agricultural University in Szczecin
}

\begin{abstract}
A hydroponic experiment has been conducted to determine the physiological and biochemical response of four new rye lines - S120, S76, OT1-3 and 541 - bred at the Department of Plant Genetics and Breeding, Agricultural University in Szczecin. Seeds were sown into soil and placed into a phytotrone chamber with controlled atmosphere and photoperiod. The relative humidity was $80 \%$, the temperature maintained at $20^{\circ} \mathrm{C}$ and the intensity of photosynthetically active radiation (Phar) was $700 \mu \mathrm{mol} \cdot \mathrm{m}^{-2} \cdot \mathrm{s}^{-1}$. Seed germination occurred after about 5 days. The seeds were characterised by different germination ability: $80 \%$ for S120, $100 \%$ for S76, $82 \%$ in OT1, and just $50 \%$ for 541 line. Rye seedlings, at the 2-3 leaf stage, were placed in hydroponic units and a two-factor experiment was set up, with potassium deficiency being the first factor and rye lines the second one. The control variant consisted of seedlings placed on complete Hoagland's medium, while potassium starvation was performed on a medium with 50\% deficiency of this element. After seven days, fresh matter was weighed, proline content was measured according to the BATES method (1973) and amounts assimilation pigments were measured according to the method of ARNON et al. (1956). The results were processed statistically, performing a two-factor analysis of variance, while the significance of factors was tested using Tukey's test at $\alpha=0.05$.

The study aimed at examining selected physiological and biochemical indicators of the resistance response of four rye lines to stress induced by potassium deficiency.

Application of $50 \%$ potassium deficiency in a medium induced an increase in the content of assimilation pigments in leaf fresh matter of S120 rye line. A correlation was found between proline content and that of assimilation pigments. The largest proline quantity, $27.2 \mathrm{\mu g} \cdot \mathrm{g}^{-1}$ f.m., was found in 541 rye line seedlings, but its content decreased together with fresh matter yield. It was also found that the total chlorophyll content was directly
\end{abstract}

dr Anna Stolarska, Chair of Plant Physiology Agricultural University, Słowackiego 17, 71-434 Szczecin, e-mail: Anna.stolarska@agro.ar.szczecin.pl, phone (091) 42-50-312 
proportional to the content of proline in S120, S76 and OT1-3 rye lines, whereas in the case of other pigments such a relationship existed only for S 120 and S76 rye lines.

Key words: rye lines, assimilation pigments, proline, fresh matter

\title{
WPLYW NIEDOBORU POTASU NA REAKCJĘ FIZJOLOGICZNĄ SIEWEK NOWYCH LINII ŻYTA
}

\begin{abstract}
Abstrakt
Celem doświadczenia było zbadanie reakcji fizjologicznej i biochemicznej 4 nowych linii żyta: S120, S76, OT1-3, 541, wyhodowanych w Katedrze Genetyki i Hodowli Roślin Akademii Rolniczej w Szczecinie. Nasiona wysiano do gleby i umieszczono w fitotronie z kontrolowaną atmosfera i fotoperiodem. Wilgotność względna wynosiła $80 \%$, temperatura $20^{\circ} \mathrm{C}$, a natężenie promieniowania fotosyntetycznie czynnego Phar $-700 \mu \mathrm{mol} \cdot \mathrm{m}^{-2} \cdot \mathrm{s}^{-1}$. Kiełkowanie nasion nastąpiło po ok. 5 dniach. Nasiona charakteryzowały się różną zdolnością kiełkowania: S120 - 80\%, S76 - 100\% OT1 - 82\%, 541 - 50\%. W hydroponikach umieszczono siewki żyta w fazie 2-3 liści i założono doświadczenie dwuczynnikowe. Pierwszym czynnikiem był niedobór potasu, drugim - linie żyta. Obiektami kontrolnymi były siewki umieszczone w pożywce pełnej Hoaglanda oraz głodzone potasem (pożywka z 50\% niedoborem tego pierwiastka). Po 7 dniach oznaczono świeżą masę (wagowo), zawartość proliny metodą BATESA (1973), zawartość barwników asymilacyjnych metodą ARNona i in. (1956). Wyniki opracowano statystycznie wykonując dwuczynnikową analizę wariancji, a istotność czynników testowano testem Tukeya na poziomie $\alpha=0,05$.

Wykazano, że niedobór potasu w pożywce spowodował wzrost zawartości barwników asymilacyjnych w świeżej masie liści żyta linii S120. Stwierdzono zależność między zawartością proliny a zawartością barwników asymilacyjnych. Największą ilość proliny $\left(27,2 \mu \mathrm{g} \cdot \mathrm{g}^{-1}\right.$ ś.m.) stwierdzono w siewkach linii 541, jednak jej zawartość malała wraz z plonem świeżej masy. Zawartość chlorofilu całkowitego była wprost proporcjonalna do zawartości proliny (S120, S76, OT1-3), natomiast pozostałych barwników tylko w przypadku linii S 120 i S76.
\end{abstract}

Słowa kluczowe: linie żyta, barwniki asymilacyjne, prolina, świeża masa, sucha masa.

\section{INTRODUCTION}

Soils contain large resources of potassium, up to $50 \mathrm{t} \cdot \mathrm{ha}^{-1}$ in a horizon to $20 \mathrm{~cm}$ deepth, but potassium available to plants makes up only $1 \%$ of its total content. Particular cereal species show different ability to take up this chemical element from soil, with the highest activity observed in oats (100\%); this activity in rye is $85 \%$ (CZUBA 1998). JAROCIŃSKI (2005) claims that cereals are vulnerable to potassium deficiency; even a moderate deficit of potassium in plant, visually hidden, manifests itself in increased transpiration, loss of turgor, accelerated wilting, decreased assimilation of $\mathrm{CO}_{2}$ and retarded growth rate and in susceptibility to bacterial and fungal diseases. Deficit of chemical elements, including potassium, in a plant is a stress factor, which, according to some authors (BANDURSKA 1991, ClaUSSEN 2002), initiates the synthesis of proline, an amino acid which is increasingly more often used for 
determining the stress level. BANDURSKA (1991) and HAWRYLAK (2007) suggest that this amino acid can fulfil a function of an adaptive metabolite, although there is no simple answer to clarify the relationships between proline accumulation and plant resistance to stress. However, it should be emphasised that proline accumulation under conditions of prolonged stress is a result of irreversible and unfavourable changes such as protein or chlorophyll decomposition and can be a symptom of injuries (BANDURSKA 2005, 2008).

This study aimed at examining selected physiological and biochemical indicators of the immune response of four rye lines to stress induced by potassium deficit.

\section{MATERIAL AND METHODS}

In order to determine the physiological and biochemical response of four new rye lines, S120, S76, OT1-3 and 541, grown at the Department of Plant Genetics and Breeding of the Agricultural University in Szczecin, a hydroponic experiment was set up. Seeds were sowed into soil and placed in a phytotrone with controlled atmosphere and photoperiod. The relative humidity and temperature were, respectively, $80 \%$ and $20^{\circ} \mathrm{C}$, while the intensity of photosynthetically active radiation Phar was $700 \mu \mathrm{mol} \cdot \mathrm{m}^{-2} \cdot \mathrm{s}^{-1}$. Seed germination took place after about 5 days. Seeds were characterised by different germination ability, i.e. $80 \%$ for line S120, 100\% for line S76, 82\% for line OT1, and only $50 \%$ for line 541 .

Rye seedlings were placed in hydropnic units in the 2-3 leaf stage according to a two-factor experimental design. Seedlings in Hoagland's complete medium were a control variant, while the second factor consisted of potassium-starved seedlings placed in a medium where potassium was in deficit amounts (50\% of the recommended dose).

After seven days the following were determined: fresh matter yield (by weighing), proline content by the method of BATES et al. (1973) and assimilation pigment content by the method of ARNON et al. (1956). The experiment was carried out in four series and six replications.

The results were processes statistically performing a two-factor analysis of variance, while significance of factors was tested with Tukey's test at $\alpha=0.05$ and correlations were examined between the proline content and the other analysed parameters. 


\section{RESULTS AND DISCUSSION}

Potassium plays an important role in water economy of plants and activation of enzymes. It also contributes to increasing the resistance of plants to frost. Under conditions of the growing deficiency of this component, chloroses of older leaves can occur (GrzeBisz a,b 2004). The effect of potassium deficiency on the amount of assimilation pigments, proline and fresh matter yield in four rye lines is presented in Table 1 as major effects. As far as the significance of interactions is concerned, the results are presented in Figure 1. In Table 2 are the relationships between the proline content and the content of respective pigments in the four rye lines.

Table 1

Mean content of fresh matter, assimilation pigments and proline in four rye lines

\begin{tabular}{|c|c|c|c|c|c|c|c|}
\hline \multirow{2}{*}{$\begin{array}{l}\text { Rye } \\
\text { lines }\end{array}$} & \multirow{2}{*}{$\begin{array}{l}\text { Fresh } \\
\text { matter } \\
(\mathrm{g})\end{array}$} & \multirow{2}{*}{$\begin{array}{c}\text { Dry } \\
\text { matter } \\
(\mathrm{g})\end{array}$} & \multirow{2}{*}{$\begin{array}{c}\text { Proline } \\
\left(\mu \mathrm{g} \cdot \mathrm{g}^{-1} \text { f.m. }\right)\end{array}$} & \multicolumn{4}{|c|}{$\begin{array}{l}\text { Assimilation pigments } \\
\left(\mu \mathrm{g} \cdot \mathrm{g}^{-1} \mathrm{f} . \mathrm{m} .\right)\end{array}$} \\
\hline & & & & $\begin{array}{c}\text { chlorophyll } \\
\mathrm{a}+\mathrm{b}\end{array}$ & $\begin{array}{c}\text { chlorophyll } \\
\text { a }\end{array}$ & $\begin{array}{l}\text { chlorophyll } \\
\text { b }\end{array}$ & $\begin{array}{l}\text { carote- } \\
\text { noids }\end{array}$ \\
\hline $\mathrm{S} 120$ & 0.242 & 0.036 & 5.0 & 1950 & 1372 & 577 & 542 \\
\hline S76 & 0.288 & 0.039 & 9.3 & 1305 & 908 & 396 & 383 \\
\hline OT1-3 & 0.184 & 0.021 & 11.6 & 1017 & 824 & 358 & 342 \\
\hline 541 & 0.135 & 0.016 & 27.2 & 1219 & 882 & 336 & 392 \\
\hline $\mathrm{LSD}_{0.05}(\mathrm{I})$ & 0.094 & 0.015 & 7.00 & 500 & 253 & 123 & 98 \\
\hline Control & 0.221 & 0.034 & 13.4 & 1149 & 863 & 369 & 365 \\
\hline $\begin{array}{c}\text { deficiency } \\
\text { of } K\end{array}$ & 0.203 & 0.032 & 11.3 & 1595 & 1131 & 465 & 464 \\
\hline $\begin{array}{l}\mathrm{LSD}_{0.05} \\
\quad(\mathrm{II})\end{array}$ & n.s.d & n.s.d & n.s.d & 263 & 132 & 64 & 51 \\
\hline $\begin{array}{l}\mathrm{LSD}_{0.05} \\
\text { (IxII) }\end{array}$ & n.s.d & n.s.d & n.s.d & 860.1 & 431.0 & 209.8 & 167.6 \\
\hline
\end{tabular}

n.s.d. - non-significant differences

Many authors (Hernandez et al. 2000, Chen Li 2002, Song et al. 2005) suggest that accumulation of free proline is an indicator of stress intensity as well as a factor that decides about an organism's repair abilities. In general, it is larger in plants that are characterised by larger resistance to stress.

Based on the results of analysis of variance, significant differences were found between the fresh matter content in the rye lines examined. Its largest yield was found in lines S76 and S120, whereas the smallest one in line 541 (Table 1). However, no significant differences were observed between the mean fresh matter content in the control variant and after application of the stress factor. Significant differences were also found between the mean 
Correlations between proline content and fresh matter yield and assimilation pigments content

\begin{tabular}{|c|l|c|c|c|c|}
\hline Character & \multicolumn{1}{|c|}{ Character } & Line S120 & Line S76 & Line OT1-3 & Line 541 \\
\hline \multirow{5}{*}{ Proline } & fresh matter & -0.28 & $-0.72^{*}$ & -0.12 & $-0.81^{*}$ \\
& dry matter & 0.32 & 0.45 & 0.36 & 0.53 \\
& chlorphyll a +b & $0.84^{*}$ & $0.96^{*}$ & $0.89^{*}$ & 0.32 \\
& chlorphyll a & $0.84^{*}$ & $0.95^{*}$ & 0.52 & 0.24 \\
& chlorphyll b & $0.85^{*}$ & $0.90^{*}$ & -0.10 & 0.49 \\
& carotenoids & $0.87^{*}$ & $0.91^{*}$ & 0.30 & 0.06 \\
\hline
\end{tabular}

* significant

proline content in the rye lines. Line 541 was characterised by the largest content of this osmoregulator, i.e. $27.16 \mu \mathrm{g} \cdot \mathrm{g}^{-1} \mathrm{f} . \mathrm{m}$. (Table 1). In the other three rye cultivars [lines], the content of proline in leaves was considerably smaller: $11.58 \mu \mathrm{g} \mathrm{g}{ }^{-1}$ f.m. in line OT1-3, 9.289 $\mu \mathrm{g} \mathrm{g}^{-1}$ f.m. in line S76 and $5.055 \mu \mathrm{g} \mathrm{g}^{-1}$ f.m. in line S120 (Table 1). Also BANDURSKA (2001) found significant differences in the content of proline in leaves in four barley cultivars. These results are the evidence that the proline level in these lines is an individual trait. Similar results in cereal plants were found by BANDURSKA (2008) and NAYYAR, WALIA (2003). On the other hand, no differences were found in the mean proline content between the control and potassiumstarved seedlings, which is verified by the results of other studies (BRAY et al. 1991, LEI et al. 2006), although BANDURSKA (2001) found that more proline was accumulated in leaves of plants which grew under a high potassium level. It is assumed that the role of potassium consists here in stimulating the activity of arginase, which catalyses conversion of arginine to proline (HERNANDEZ et al. 2000).

Potassium deficiency contributed only slightly to degradation of assimilation pigments (Table 1, Figure 1) in line S76, which points to a small resistance of this line to deficit of this chemical element in soil. On the other hand, S120 was characterised by the significantly largest content of assimilation pigments, with their concentration increasing after application of potassium in a dose smaller by $50 \%$ than the recommended one.

The relationships between the proline concentration and the yield of fresh matter and the content of assimilation pigments were also analysed in the study (Table 1). In the case of lines $\mathrm{S} 76$ and 541, the proline concentration was positively correlated with the fresh matter yield. In lines S120 and S76, the content of assimilation pigments was directly proportional to th proline concentration. Similar results were obtained by GADALLAH (1999), who examined the influence of water stress on Vicia faba. He found that the contents of chlorophyll $\mathrm{a}$ and $\mathrm{b}$ enlarged with an increase in the proline content. 



Fig. 1. Effect of potassium deficiency on assimilation pigments content

\section{CONCLUSIONS}

1. Potassium deficiency in a medium induced an increase in the content of assimilation pigments in fresh matter in rye line S120. It was also found that increase in the content of assimilation pigments occurred with a simultaneous increase of the proline content in leaf fresh matter.

2. The largest amount of proline was found in line 541 seedlings, i.e. $27.2 \mu \mathrm{g} \cdot \mathrm{g}^{-1} \mathrm{f}$.m.; moreover, the content of proline in this line and in line S-76 increased with a simultaneous decrease in the yield of fresh matter in seedlings.

3. Line S76 proved to be most vulnerable to potassium deficiency in medium; the effect of the stress factor induced a clear decrease in the contents of assimilation pigments and of fresh matter. 


\section{REFERENCES}

Bandurska H. 1991. Akumulacja wolnej proliny jako przejaw metabolicznej reakcji roślin na dziatanie stresu wodnego. Wiad. Bot., 35: 35-46 .

Bandurska H., 2001: Proline accumulation during hardening and its involvement in reducing membrane injuries in leaves subjected to severe osmotic stress. Acta Physiol. Plant. 23:483-490.

Bandurska H., GóRny A.G., Zielezińska M.2008. Effects of water deficit on the relative water content, proline accumulation and injury of cell membranes in leaves of old and modern cultivars of winter wheat. ZPPNR, 524: 115-126.

Bandurska H., Stroiński A. 2005. The effect of salicylic acid on barley response to water deficit. Act. Physiol. Plant., 27: 379-386.

Bray L., Chriqui D., Gloux K., Le Rudulier D., Meyer M., Pedizzi J.1991. Betaines and free amino acids in salt stressed vitro plants and winter resting bud sof Populus trichocarpa x deltoids. Physiol. Plant., 83:136.

CHEN W .P., Li I P.H. 2002. Membrane stabilization by abscisic acid under cold aids proline In alleviating chilling injury In maize (Zea Mays L.) cultured cells. Plant Cell. Environ., 25: 955.

Claussen W. 2002. Growth water use of efficiency and proline control of hydroponically grain tomato plants as affected by nitrogen source and nutrient concentration. Plant Soil, 247:199-209.

Czuba R.1998. Potas - niezbędny sktadnik pokarmowy zbóż ksztattujący wielkość i jakość plonu ziarna. IUNG.

Gadallah M.A. 1999. Effects of proline and glicynebetaine on Vicia faba responses to salt stress. Biol. Plant., 42 (2): 249-257.

Grzebisz W. 2004a. Potas - system nawożenia. AR Poznań, s. 30.

Grzebisz W. 2004b. Potas a stresy. Potas w produkcji roślinnej. Międz. Inst Potasowy, Bazylea, $52-61$.

HaWRYLAK B. 2007. Fizjologiczna reakcja ogórka na stres zasolenia w obecności selenu. Rocz. AR Poznań, 383:483-486.

Hernandez S., Deleu C., Larher F. 2000. Accumulation de praline danes les tissues foliaires de tomate en response a la salinite life. Sci. Plant Biol. Pathol., 23: 551-557.

JAROciński B.Z. 2005. Rola i funkcje potasu $w$ roślinie. MODR, Warszawa, s. 3.

LeI Y., Yin C., Li C. 2006. Differences in some morphological physiological and biochemical response to drought stress in two contrasting populations of Populus przewalski. Physiol. Plant., 127: 182-191.

NAYYAR H., WALIA D.P. 2003. Water stress induced proline accumulation in contrasting wheat genotype as affected by calcium and abscisic acid. Biol. Plant., 46:275-279.

Song S.Q., Lei Y.B., Tian X.R. 2005. Proline metabolism and cross tolerance to salinity and heat stress in germinating wheat seeds. Rus. J Plant. Physiol., 52 (6):793-800. 
